\title{
ENTREVISTA: PROFESSORA MARCIA CHAME
}

\author{
INTERVIEW: PROFESSOR MARCIA CHAME
}

\author{
Entrevistadora: Anne-Marie Pessis ${ }^{1}$
}

annepessis@gmail.com

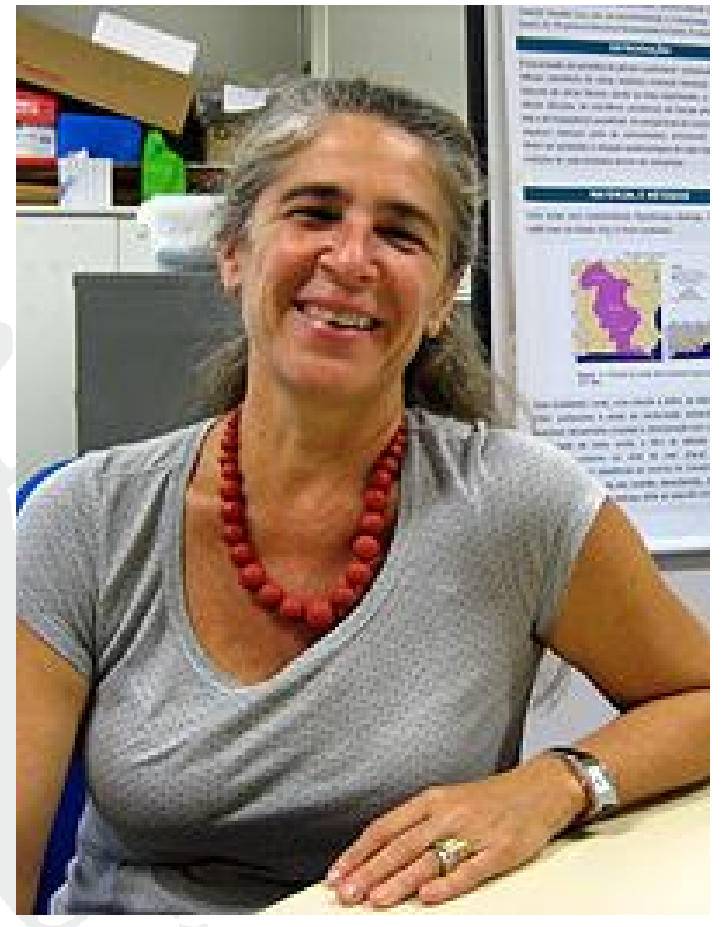

Bióloga, com mestrado e doutorado em Ciências Biológicas (Zoologia) pela UFRJ, realizou, durante o mestrado, estudos comparativos de coprólitos no Parque Nacional Serra de Capivara e, no doutorado, estudou os reservatórios de água e suas implicações na distribuição do espaço dos mamíferos no semiárido. É Pesquisadora Titular da Fiocruz, pesquisadora da Fundação Museu do Homem Americano, Membro Titular representante do Ministério da Saúde no Conselho Nacional da Biodiversidade do Ministério do Meio Ambiente, Coordenadora da Plataforma Institucional de Biodiversidade e Saúde Silvestre da Fiocruz Atualmente pesquisa temas relacionados à Ecologia, Parasitologia, a relação da saúde de animais silvestre e humana e a emergência de zoonoses.

\footnotetext{
${ }^{1}$ Fumdham, Programa de Pós-graduação em Arqueologia, UFPE.
} 
Clio: Observa-se nas suas pesquisas que, desde o início, acham-se articuladas com diversas disciplinas que partilham o estudo da interação de populações humanas e do ambiente, desde a pré-história aos dias atuais em torno do Parque Nacional Serra da Capivara. Como se gera essa articulação científica?

Marcia Chame: O que sempre me fascinou na pesquisa científica foram os processos. Descobrir como a natureza se organiza, como estabelece suas interrelações e suas conexões. Assim, trabalho mais com a ecologia que com a zoologia clássica. Isso sempre abriu portas; nunca me coloquei limites.

\section{Clio: Como a você chegou à Fiocruz?}

Marcia Chame: Na graduação tive como professor o Comandante Luís Antônio de Carvalho Ferraz que foi muito importante na minha formação. Como me dedicava

\section{Trabalho mais com a} ecologia que com a zoologia clássica

aos estudos de biologia marinha e oceanografia, um dia ele me perguntou se eu queria embarcar no navio de Jacques Cousteau na expedição do Calypso à Amazônia. Fiquei muito entusiasmada. Tinha 15 dias para apresentar um projeto numa concorrência. Com um colega de estudos ficamos sem saber o que fazer. Era necessário achar um tema diferente que nos desse a chance de ganhar a concorrência. Decidimos estudar as verminoses nas populações ribeirinhas daquela região. 
Um professor da universidade nos ajudou a fazer o projeto, mas ele adoeceu. O nosso projeto foi aprovado e ficamos sem saber como nos capacitar para desenvolver o que tínhamos planejado. Fui então pedir ajuda ao diretor do Hospital Evandro Chagas da Fiocruz, médico de meu pai, que me encaminhou ao Professor Luiz Fernando Ferreira que nos acolheu e nos ajudou a desenvolver o projeto. Foi o primeiro contato científico com a Fiocruz. Tínhamos três meses

Um dia me perguntou se eu queria embarcar no

\section{navio de Jacques \\ Cousteau em uma} expedição na Amazônia para aprender os procedimentos para implantar o projeto. O Professor Luís Fernando Ferreira foi o criador da paleoparasitologia no mundo e seu interesse era estudar as doenças das populações isoladas e antigas e o parasitismo dessas populações.

Ele nos abriu as portas de seu Laboratório e aceitou que fossemos trabalhar com ele e estudar as parasitoses nas populações ribeirinhas do rio Amazonas. Três meses depois estávamos prestes a embarcar, mas recebemos uma carta de Jacques Cousteau informando a cancelamento das operações por motivos operacionais. Foi uma decepção imensa, não sabia o que fazer a essa altura, já me formando. 
Mas o Professor Luiz Fernando me propôs de fazer meu mestrado com um novo desafio, entrar na Paleoparasitologia. Assim foi que me integrei à FIOCRUZ.

\section{Clio: Como a você entrou em contato com pesquisas no Parque Nacional Serra da Capivara?}

Marcia Chame: Na época, Niéde Guidon estava em um congresso no Rio de Janeiro e o Professor Luiz Fernando mandou que fossemos conversar com os arqueólogos para explicar nosso

Trabalhar com os coprólitos permitiria saber sobre a vida dos animais sem capturá-los interesse de receber coprólitos que fossem achados nas escavações. Ele já havia feito contato com ela e nós já havíamos recebido algumas amostras do Piauí. A partir deste encontro iniciamos então a

parceria da Fiocruz com a Missão Arqueológica Franco-Brasileira ao Piauí para estudar coprólitos, pois não se sabia de quem eram os coprólitos, se eram de humanos, se eram de animais e nesse caso de que espécie. No congresso de Arqueologia no Rio de Janeiro, a Professora Niéde achou muito bom que zoólogos e médicos pesquisassem no Parque Nacional, pois era necessário criar uma metodologia para reconhecimento dos coprólitos. 
Em julho de 1984, fomos ao Piauí, eu e Adauto Araújo2, que desejava estudar as doenças das populações humanas e eu as dos animais. Ao invés do mar, cheguei a uma região que não tinha nem água. Uma relação entre dois mundos completamente diferentes. Começamos a pensar nessa metodologia, para entender aquele processo de preservação de coprólitos e o universo que podia ser descoberto. Compreender as informações que os coprólitos podem fornecer é um universo de conhecimento novo.

Achamos que esse verme tivesse sumido por conta das mudanças climáticas globais
Podemos encontrar restos de alimentos e identificar não só a dieta, mas que animais e plantas existiam naquela localidade na época, identificando o DNA, é possível saber quem eram aqueles indivíduos. Doenças que eles tinham e seus hábitos.

O estudo dos animais, sem experimentação no laboratório, foi sempre para mim uma escolha. Trabalhar com os coprólitos permitiria saber sobre a vida dos animais sem capturá-los. A essa metodologia se foram incorporando outras tecnologias como as técnicas moleculares para identificação de DNA, métodos químicos e a partir deles se abrem um universo de descobertas. Para criar a base comparativa de amostras do passado, capturamos animais para obter as fezes e depois os soltávamos. Com o estabelecimento da metodologia, hoje não é

\footnotetext{
${ }^{2}$ Em 2015 a Clio Arqueológica entrevistou o Professor Adauto José Gonçalves de Araújo. Indexadores: Latindex, ISIS, Google Academic
} 
necessário capturar os animais e podemos usar a coleção de fezes recentes como base comparativa para os estudos com coprólitos e ainda mais, podemos comparar as mudanças de hábitos, dieta e parasitos ao longo das alterações ambientais e climáticas ocorridas na região.

Hoje temos mais de 6.000 amostras de fezes atuais de mais de 60 espécies de mamíferos, répteis, aves e anfíbios. Também se formou a coleção de Paleoparasitologia com coprólitos pré-históricos e outros materiais que permitem o estudo de parasitos. Duas coleções que se apoiam uma na outra.

\section{Clio: Esse estudo permite resultados conclusivos?}

Marcia Chame: Temos algumas possibilidades de trabalho. Ao longo destes anos e graças ao número de escavações realizadas na região do Parque Nacional Serra da Capivara, podemos acompanhar a presença de um verme intestinal (Trichuris sp.; Nematoda), parasito do mocó (Kerodon rupestris), um roedor endêmico da Caatinga. Este verme se mantém neste hospedeiro desde 30.000 anos até hoje, resistindo e possivelmente modificando sua estratégia de transmissão. Num determinado momento, não encontramos ovos desses vermes nos coprólitos de mocós mais recentes que 8.000 anos e achamos que eles tivessem desaparecido daquela população por conta das mudanças climáticas. Chegou-se a publicar isso. A explicação plausível na época era que o processo de mudança climática, na região que hoje é a Caatinga e que antes era a fronteira entre Amazônia e a Mata 
Atlântica (clima tropical úmido), tivesse impedido a sobrevivência dos ovos do verme no solo, mais quente e seco.

No entanto, coletando a 90km a oeste da Serra da Capivara encontramos os ovos de Trichuris em fezes de mocós atuais, mostrando que permaneciam bem próximo da Serra da Capivara. Tratamos então de aumentar o esforço de análise de coprólitos e de coleta das fezes

Se não fossem os arqueólogos que coletam os coprólitos seria impossível pesquisar em paleoparasitologia atuais numa área de 400mil km2 acima do rio São Francisco. Assim poderíamos identificar e tentar compreender como os mocós e seus parasitos se distribuem e se mantém. Com o aumento do esforço de análise e coleta,

começamos novamente a achar esse verme. Este fenômeno nos fez repensar tudo o que se pensava até então. A presença ininterrupta do Trichuris nos mocós e o encontro de outras espécies nos apontam processos de adaptação dessa fauna à transformação semiárida.

Hoje, a distribuição encontrada dos mocós e seus parasitos e os modelos gerados de distribuição, nos indicam que com a dessecação do ambiente estes animais provavelmente restringiram sua área de vida especialmente aos enclaves mésicos, 
às bordas das serras e interior dos cânions, onde o clima ameno e a densidade populacional do roedor favorecem a transmissão do parasita. Esse resultado, só possível com o acumulo de dados de cerca de 30 anos de pesquisa, mostra também como a relação entre parasitos e seus hospedeiros podem funcionar ao longo das mudanças climáticas e ambientais.

Clio: Como se deu a relação entre a pesquisa ecológica aplicada e a arqueologia?

Povos pré-históricos dessa região colocavam pedras dentro dos caldeirões quando se sentiam ameaçados por um grupo que vinha de fora
Marcia Chame: Isso é o que mais interessa. É essa relação muito legal desse estudo, porque ela só é possível com a interdisciplinaridade com arqueologia. Se não fossem os arqueólogos

que coletam os coprólitos seria impossível pesquisar em paleoparasitologia. Se não fossem as informações do paleoambiente construídas a partir dos estudos arqueológicos e paleontológicos não seria possível fazer essas inferências. É onde as ciências se encontram, os conhecimentos se encontram e a partir da junção desses conhecimentos se consegue fazer um salto para conhecimentos que ainda não se têm. Trabalhar com uma equipe interdisciplinar é fascinante. Isso eu aprendi com a Professora Niéde Guidon, na Fumdham. O estudo de fezes pode ter 
outras aplicações. Dentro das quais e uma delas é o manejo da fauna do Parque Serra da Capivara.

Em 1990 estávamos fazendo o plano de manejo do Parque, precisávamos construir o processo de conservação de toda a riqueza daquela área. Queríamos identificar qual era a dinâmica da fauna, como era que os animais utilizavam o Parque, durante a seca e durante a chuva. Muitas questões se colocavam em relação a isso. Embora muitas espécies na Caatinga consigam retirar água de seu alimento, elas não são independentes de água livre. E se elas precisam de água, como é essa dinâmica num parque que não tem água. Nessa época estávamos todos muito preocupados porque as onças começavam a sair do Parque para predar as criações nas áreas vizinhas e ir a buscar água nos rios cujas margens estavam ocupadas pelas pessoas. Iniciava-se o processo de isolamento do Parque, com a redução de populações de presas que pudessem suportar as de predadores. Outro problema muito concreto era como poderíamos ajudar a reestabelecer o equilíbrio dentro de um parque nacional que tinha sido utilizado para a caça durante tanto tempo.

Essas questões eram sem levantadas e discutidas pelo pesquisadores. Discutia-se questões como fazer bebedouros ou não fazer bebedouros, a utilização do modelo de bebedouros de Austrália ou o modelo americano. Não chegávamos a uma solução boa para a região. Mas, um dia fui a conversar com a Professora Niéde Guidon sobre um assunto trivial no sítio do Boqueirão da Pedra Furada e ela 
começou a me mostrar a sedimentação desse Sítio, que tinha uma discordância de sedimentos. Face da presença do caldeirão (reservatório de água escavado naturalmente na rocha) ao lado do sítio estar coberto de pedras e sem água, ela falou que talvez fosse possível que os povos pré-históricos dessa região colocassem pedras dentro dos caldeirões quando se sentiam ameaçados por um grupo de humanos que vinham de fora. Essa poderia ser uma maneira de mostrar que ali não tinha água, como uma informação dissuasiva. Depois que o perigo desaparecia limpariam os caldeirões e voltariam a utilizar aquele lugar.

Quando ela falou isso eu pensei que seria muito legal fazer o manejo da água utilizando as informações da pré-história e aquelas de grupos humanos de tradição oral. Assim passei dez anos da minha vida catando caldeirões de água. Fizemos o levantamento de todos os caldeirões do parque, sua localização, sua capacidade de abastecimento, o período que armazenam água, que tipo de acesso aos animais proporcionam, pois alguns são seletivos em algumas situações. Com essa informação consegui juntar as duas coisas. A metodologia de identificação dos coprólitos e das fezes permitiu conhecer o uso dos caldeirões pelos animais e a importância destes pontos para a dinâmica da fauna e a identificação dos parasitos dos animais, junto com o estudo da qualidade da água, possibilitaram identificar espécies patogênicas e a potabilidade da água para o uso animal e humano. 
Os parasitos nos contam essas histórias. Hoje se pode entender esse parque não apenas do ponto de vista atual, mas como o conjunto de espécies utilizam o parque desde a pré-história.

Essas inter-relações foram se estreitando ao longo dos estudos e dos resultados, por que entre os parasitos de animais estavam, e ainda estão, espécies que também parasitam os humanos. Então, a relação entre a biodiversidade e a saúde humana se dá ao longo do processo evolutivo, das migrações humanas e das mudanças ambientais. E é exatamente isso que os resultados do nosso grupo de Paleoparasitologia e de outros pesquisadores mostram. O modo de vida dos parasitas espelham a vida de seus hospedeiros.

Daí comecei a construir um outro processo e a buscar sobre como a saúde humana e animal se transformam a partir de impacto humano na biodiversidade. A perda e as modificações da biodiversidade impactam a nossa saúde e a saúde dos animais, abrindo possibilidades de novas doenças e de novos conhecimentos, incluindo outros organismos como os vírus, fungos e muitos outros.

Esses conhecimentos da área da saúde podem ajudar os pesquisadores que trabalham e se expõem a possíveis organismos que permanecem nas camadas sedimentares dos sítios arqueológicos e paleontológicos. Conhecendo os riscos, é possível se prevenir de perigos que não se conheciam e a buscar e compreender a necessidade de utilizar equipamentos de proteção individual (EPIs). Em alguns 
dos nossos projetos, integramos a nossa equipe especialistas em fungos ambientais da Fiocruz, que nos instruem e auxiliam nessa prevenção.

Na escavação da Lagoa do Uri de Cima, em Pernambuco, foi possível encontrar fragmentos do DNA de um fungo (Histoplasma capsulatum) que vive no ambiente, mas que também é patogênico até os dias de hoje em humanos e animais. O DNA estava preservado no conglomerado datado de 30.000 anos e sua

\section{Existe uma estreita} relação entre

\section{biodiversidade e a saúde humana}

presença indica que as pessoas na escavação estavam expostas à contaminação deste e de outros fungos que vivem no solo. Esse encontro motivou a compreensão dos riscos à saúde associados aos profissionais que trabalham em

escavações arqueológicas e paleontológicas. Agora, todas as pessoas que escavam utilizam máscaras para proteção de organismos da classe de risco NB2 e luvas. Poucas são as pessoas que sabem que no nordeste e em outras áreas do Brasil existe alto índice de impacto de fungos do solo sobre a saúde. Essas relações apenas exemplificam como os conhecimentos podem se conectar. E claro, ainda seria importante saber se as preguiças gigantes encontradas na Lagoa do Uri de Cima estavam ou não infectadas por Histoplasma capsulatum. Há ainda muitas perguntas sem respostas. 


\section{Clio: E o futuro?}

Marcia Chame: Antes se trabalhava buscando apenas as espécies no passado. Hoje trabalhamos relacionando a complexidade de dados para montar cenários para o futuro. Os estudos realizados ao longo do tempo no nordeste, em espacial na Serra da Capivara, nos mostra como as parasitoses se transformaram e acompanharam a formação do bioma Caatinga e o modo de vida dos que lá viviam.

Os processos atuais de perda da biodiversidade e do aumento dos bolsões de desertificação são fatores que gerarão impacto sobre a saúde e a economia regional. Em outros estudos, com outras espécies, observamos que nas áreas onde a Caatinga é mais preservada, os animais apresentam maior diversidade de helmintos, mas com carga parasitária baixa. Nas áreas degradadas, a riqueza de espécies de parasitos diminui drasticamente, mas são as espécies de maior patogenicidade que se mantém. Esse resultado aponta que esses processos estão selecionando as espécies com maior capacidade de adaptação às áreas degradadas e que são essas, justamente, aquelas com maior capacidade de transmissão e de provocar doenças. Esses resultados se corroboram com diversos outros estudos que mostram que a maior riqueza de hospedeiros e vetores, além da competição entre parasitos, tende a diluir a transmissão de espécies patogênicas. E isso é preocupante quando se pensa nos cenários e nas alterações climáticas que já se instalam e no futuro. 